NSF, few, if any, new grants are being awarded.

Conservatives pooh-pooh the public alarm that the White House raised this week in a last-ditch effort to persuade Congress to avert the cuts. What programme of the oversized US government, they ask, cannot find $5 \%$ in excess fat to trim? Unfortunately, science agencies have very little. At the NIH, for instance, funding rates for grant applicants are already at historic lows: the agency spends roughly $85 \%$ of its budget in the extramural community, yet the chance of winning a competitive grant has fallen from about one in three 10 years ago to around one in six today. At the NSF, the odds are only slightly better, at just over one in five.

The risk is that these numbers will begin to look generous as the sequester takes effect. On 25 February, NIH director Francis Collins predicted that "hundreds and hundreds" of new grants, and grants competing for renewal, will not be awarded if the sequester takes effect. Furthermore, the agency has been holding back money from the instalments it owes on multi-year grants that were awarded in previous years; at any point in time, these constitute the bulk of its extramural spending and they will need to be cut to reach the \$1.6-billion mark. Such instalments have been funded at $90 \%$ so far this year; under the sequester, awardees will never see the full $100 \%$.

The outlook is no merrier at other science agencies. NSF director Subra Suresh wrote to Senator Barbara Mikulski (Democrat, Maryland) this month that he will be obliged to reduce his portfolio by nearly 1,000 grants and to terminate $\$ 35$ million in contracts for work already in progress on major facilities for environmental and oceanographic research. At the Department of Energy, cuts to the basic science mission will be "severe", director Steven Chu wrote to Mikulski this month, affecting an estimated 25,000 researchers and

operations-support staff at the ten national labs and compelling a reduction in both the size and the number of the department's grants.

Opponents of the sequester worry not only about its effects, but also that the public is likely to notice them only gradually. For instance, the tens of thousands of government employees who are expected to be lost from agencies such as the Food and Drug Administration require 30 days' notice, pushing noticeable effects into

"Researchers will leave the country, or they will leave science."
April. The loss 2,000 disease trackers supported by the Centers for Disease Control and Prevention might not become apparent until the next time Salmonella poisons peanut butter. By the time the public outcry becomes sufficient to cause Congress to enact a remedy for the sequester, significant damage is likely to have been inflicted on science and on public health, not to mention the vast reaches encompassed by the rest of the government.

But for research, what is most deeply troubling about the looming cuts is not the absolute dollars lost or the immediate damage done, painful as that will be. It is what they both signify and portend, as the work of a profoundly divided government that shows no sign of being able to deliver, in anything like the foreseeable future, the stable, predictable funding that excellent science requires. Without that stability and predictability, not only will the United States' lead in science and innovation continue to erode in the face of international competition, but, in an age of unparalleled scientific opportunity, the next generation of would-be researchers will begin, understandably, to vote with their feet. They will leave the country, or they will leave science. Either way, the United States and its people will lose.

\section{Prize drawback}

\section{The narrow distribution of awards aimed at the broad arena of the 'life sciences' raises concerns.}

$\mathrm{R}$ ecipients of the newly established Breakthrough Prize in Life Sciences were said to have been 'floored', not just by the award, but also by the sum of money involved. At US\$3 million per laureate, the prize dwarfs the Nobel Prize in Physiology or Medicine — which in 2012 totalled 8 million Swedish Krona, or \$1.2 million - especially given that that is often shared between two or three individuals. The objective of the Breakthrough Prize, according to its website, is "to recognize excellence in research aimed at curing intractable diseases and extending human life"; however, the web page also says that the prizes are given for "accomplishments in life sciences broadly defined".

By the first criterion, the list of laureates is fair enough. The 11 recipients, all scientists in the front rank, work in the biomedical sciences, and the word 'cancer' appears in the citations for seven of them. The second criterion is more problematic. Any reading of the life sciences as 'broadly defined' must extend beyond (valuable and necessary) research into cures for diseases that mainly affect people in wealthy nations. There is no mention in any of the awards of malaria, schistosomiasis, cholera or malnutrition.

Taking an even broader view, the narrow scope of the prizes awarded excludes any discipline that considers the attributes of living organisms in general. Genetics gets a look in (knowledge of genetics illuminates disease states) but there is little recognition of developmental biology or neurobiology, and nothing at all on evolution, ecology, parasitology, demography, biomechanics, microbiology, environmental science, zoology, botany, conservation biology, systematics, taxonomy, palaeontology, geobiology or even astrobiology.
The apparent blind spot of the prize-givers towards these fields has been criticized in the wake of the awards, often by people in those very fields. But there is more to this than an academic turf war and sour grapes. In recent decades, the life sciences have split into two camps that can be summarized as the biology of cells and the biology of organisms. Perhaps because of their closeness to medicine, cell biologists have assumed the ascendant, and attract most funding. This has led to a perception - at least among those who study whole organisms - that cell biologists regard their own discipline not only as important (which it is) but as the only kind of biology that matters (which it is not).

Solutions to many of the world's problems will demand intensive research in many disciplines that are too-often excluded from even broad definitions of the life sciences. Efforts to mitigate the effects of climate change will require a detailed inventory of the world's species (biodiversity, zoology, botany, taxonomy, microbiology, marine biology and so on) and their interactions with one another (ecology) and the environment.

Research into many of these areas is undertaken in museums. At the time the Breakthrough Prize was announced, the Field Museum of Natural History in Chicago, Illinois, was facing tough decisions over a major shortfall in income. It is in the process of disbanding its separate research departments, reducing both the museum's capacity for research into biodiversity and its high quality of educational outreach - crucial in a nation in which the very idea of evolution is perpetually under threat.

Further cuts will be necessary; the museum announced in December that it will have to slash $\$ 3$ million from its research budgets (see Nature http://doi.org/j6q; 2012): an amount, coincidentally, that is equivalent to just one Breakthrough Prize, given to just one researcher in life sciences as defined by the Breakthrough Prize Foundation. It is
SNATURE.COM To comment online, click on Editorials at: go.nature.com/xhunqv a laudable aim to work for ways to prolong lives, even those that are already long and luxurious. To work for a world that can harbour billions of human beings in tolerable comfort is also worthy of recognition. 